\title{
Evaluating the Digestibility of Ammonia Fermented (Amofer) Corn Cob Using Different Levels of M21 Decomposer and Urea (In Vitro Study)
}

\author{
Restuti Fitria*, Siti Rahmawati Zulaikhah and Novita Hindratiningrum \\ Animal Husbandry Departement, Nahdlatul Ulama Purwokerto University, Purwokerto, Indonesia \\ *Corresponding author email: restutifitria@gmail.com
}

\begin{abstract}
This research aimed to evaluate the addition of M21 Decomposer (MD) and urea (U) on the Dry matter digestibility (DMD) and Organic matter digestibility (OMD) in vitro. There were five treatments and five replicates. The treatments in this study were the addition of $M D$ and $U$ at different levels. namely $R 0=$ Corn cob without amofer/control; R1 = Amofer Corn cob plus 0.04\% MD+3\% U; R2 = Amofer Corn cob plus $0.06 \%$ $\mathrm{MD}+3 \% \mathrm{U} ; \mathrm{R} 3=$ Amofer Corn cob plus $0.04 \% \mathrm{MD}+5 \% \mathrm{U}$; and $\mathrm{R} 4=$ Amofer Corn cob plus $0.06 \% \mathrm{MD}+5 \% \mathrm{U}$. The obtained data were subjected to Analysis of Variance and continued by an Orthogonal Contrast. The result showed that the treatments significantly affected $(P<0.05)$ both DMD and OMD digestibility. The digestibility of amofer corncob was higher than the non-amofer that exhibited $17.982 \pm 2.4409 \%$ DMD and $26.024 \pm 3.009 \%$ OMD. The highest DMD and OMD digestibility was observed in R4. i.e.. $24.655 \pm 4.858 \%$ and $34.276 \pm 5.176 \%$. respectively. In conclusion. the best level in the incorporating $\mathrm{MD}$ and $\mathrm{U}$ is at $\mathrm{MD} 0.06 \%$ and $\mathrm{U} 5 \%$ could improve DMD by $6.673 \%$ and OMD by $8.252 \%$.
\end{abstract}

Keywords: amofer, corn cob, digestibility, dry matter, organic matter

Abstrak. Tujuan dari penelitian ini adalah untuk mengevaluasi level penambahan M21 Dekomposer (MD) dan urea (U) terhadap Kecernaan Bahan Kering (KBK) dan Kecernaan Bahan Organik (KBO) secara in vitro. Terdapat 5 perlakuan dengan masing-masing perlakuan diulang sebanyak 5 kali. Perlakuan dalam penelitian ini adalah penambahan $M D$ dan $U$ pada level yang berbeda $\left(R_{0}=\right.$ Janggel Jagung tanpa amofer $/$ kontrol; $R_{1}=$ Amofer Janggel Jagung meggunakan 0,04\% $\mathrm{MD}+3 \% \mathrm{U} ; \mathrm{R}_{2}=$ Amofer Janggel Jagung menggunakan $0,06 \% \mathrm{MD}+3 \% \mathrm{U} ; \mathrm{R}_{3}=$ Amofer Janggel Jagung menggunakan $0,04 \% \mathrm{MD}+5 \% \mathrm{U}$; dan $\mathrm{R}_{4}=$ Amofer Janggel Jagung menggunakan $0,06 \%$ $\mathrm{MD}+5 \% \mathrm{U}$ ). Data yang diperoleh kemudian di Analisis Variansi (ANAVA) dan dillanjutkan dengan Uji Orthogonal Kontras. Hasil penellitian menunjukan bahwa perlakuan berpengaruh nyata $(P<0,05)$ terhadap kecernaan baik KBK maupun KBO. Hasil menunjukan bahwa kecernaan pada janggel jagung yang diamofer lebih tinggi dibanding janggel jagung tanpa amofer dimana KBK janggel jagung tanpa amofer hanya sebesar $17,982 \pm 2,4409 \%$ dan KBO sebesar $26,024 \pm 3,009 \%$. Kecernaan paling tinggi baik KBK maupun KBO diperoleh pada amofer jangggel jagung perlakuan $\mathrm{R}_{4}$ yaitu kecernaan bahan kering sebesar $24,655 \pm 4,858 \%$ dan kecernaan bahan organik sebesar $34,276 \pm 5,176 \%$. Kesimpulanya adalah, level terbaik terdapat pada kombinasi MD 0,06\% dan Urea 5\% yang mampu meningkatkan KBK sebesar 6,673\% dan KBO sebesar 8,252\%.

Kata kunci: amofer, janggel jagung, kecernaan, bahan kering, bahan organik

\section{Introduction}

Corn cob is a part of corn plant that becomes an agricultural waste. Meanwhile, corn cob is the potential feed for livestock, especially ruminants. Cornfields cover an area of 52.8054 ha across Central Java province, producing 3,212,391 tons in 2015 (Central Java BPS, 2018) and keeps increasing in the past five years. As a result, corn cobs are vastly available for feed, but the quality is poor. Low digestibility and protein content contribute to the low-quality corn cob, so it is crucial to perform advanced treatments to the cobs before feeding.

Ammoniation and fermentation are two combined techniques in feed processing that could improve the quality of corn cob as animal feed. Ammonia works in detaching lignincellulose bound and providing $\mathrm{N}$ source for the growth of microbe. Meanwhile, fermentation improves digestibility and crude protein in the corn cob (Prastyawan et al., 2012). Ammoniation may use urea as the source of $\mathrm{N}$, 
and fermentation may use a commercial starter (M21 Decomposer) as the source of microbe.

However, the level of use of M21 Decomposer and urea in the amofer process still needs to be evaluated to determine its effect on digestibilty. This study aims to evaluate the additional level of M21 Decomposer and urea and their effect on the digestibility of both dry matter and organic matter.

\section{Materials and Methods}

The materials consisted of (1) corn cobs from harvested and chopped hybrid yellow corn; (2) M21 Decomposer containing various microbes including Pseudomonas, Actinomycetes, Lactobbacillus, Acetobacter, Trichoderma and Rhizobium; (3) N content in urea; and (4) water. The study conducted an in vitro experiment using a method by Tilley and Terry (1963) in a Completely Randomized Design, assigning five treatments, and five replicates. The treatments were $\mathrm{RO}=\mathrm{Corn}$ cob without amofer/control; R1 = Amofer Corn cob plus $0.04 \% \mathrm{MD}+3 \% \mathrm{U} ; \mathrm{R} 2=$ Amofer Corn cob plus $0.06 \% \mathrm{MD}+3 \% \mathrm{U} ; \mathrm{R} 3=$ Amofer Corn cob plus $0.04 \% \mathrm{MD}+5 \% \mathrm{U}$; and R4 = Amofer Corn cob plus $0.06 \% \mathrm{MD}+5 \% \mathrm{U}$. The measured variables included Dry matter digestibility (DMD) and Organic matter digestibility (OMD). The obtained data were subjected to analysis of variance (ANOVA) to evaluate the effect of treatments on the measured variables, continued by an Orthogonal Contrast test.

\section{Results and Discussion}

Dry matter digestibility and Organic matter digestibility (Table 1 ) showed that the ammonia fermentation (amofer) using M21 Decomposer and urea on the corn cobs could increase the DMD and OMD. The data illustrated that DMD and OMD of amofer corn cobs in the treatment
$R 1, R 2, R 3$, and R4 were higher $(P<0.05)$ than those of control/without amofer treatment (RO). Furthermore, the analysis showed that the highest $\mathrm{DMD}$ and $\mathrm{OMD}$ were obtained from the amofer corn cobs in treatments R4 with an additional 0.06\% M21 Decomposer and 5\% urea. Meanwhile, DMD and OMD across treatments R1, R2, and R3 were not significantly different $(P>0.05)$. It demonstrates that incorporating M21 Decomposer and Urea could increase DMD and OMD.

\section{The effect of treatments on dry matter digestibility}

The result of DMD analysis showed that treatment RO was significantly different $(P<0.05)$ from R1, R2, R3, and R4. Incorporating M21 Decomposer and Urea could increase the corn cobs DMD due to the loose lignin-cellulose bound as a result of the ammoniation and fermentation process that pre-digest the complex compounds outside the rumen with the help of microorganism in the M21 Decomposer. It was in line with Prastyawan et al. (2012) that the DMD of corn cobs treated with ammonia fermentation would increase as the level of starter improved.

The result of $D M D$ analysis on treatment $R 4$ showed a highly significant difference $(P<0.01)$ from that of treatment R3. Dry matterr digestbiility of the $R_{4}$ treatment increased by $6.673 \%$ compared to untreated corn cobs $\left(R_{0}\right)$. Dry matter digestibility represents the total digestible nutrition by the ruminal microbes. Therefore, the higher the DMD, the more nutritions digested by the ruminal microbe. The highest additional level of M21 Decomposer and urea was in R4 of all treatments. As a result, R4 had the highest digestibility of amofer corn cobs. Yulistiani et al. (2011) stated that incorporating $3 \%$ urea into the corn cobs could increase dry matter digestibility by $31 \%$ and organic matter digestibility by $43 \%$. 
Table 1. In vitro digestibility

\begin{tabular}{|c|c|c|}
\hline Variable & DMD (\%) & OMD (\%) \\
\hline F count & $4.020 *$ & $4.179 *$ \\
\hline F tab 0.05 & 2.866 & 2.866 \\
\hline RO & $17.982 \pm 2.409$ & $26.024 \pm 3.009$ \\
\hline R1 & $21.277 \pm 1.561$ & $30.91 \pm 2.818$ \\
\hline R2 & $20.483 \pm 2.928$ & $28.213 \pm 3.066$ \\
\hline R3 & $18.777 \pm 1.299$ & $29.527 \pm 1.954$ \\
\hline R4 & $24.655 \pm 4.858$ & $34.276 \pm 5.176$ \\
\hline Contrast & F hit & F hit \\
\hline F table 0.05 & 4.351 & 4.351 \\
\hline R0 vs R1,R2,R3,R4 & $5.223 *$ & $7.7740^{*}$ \\
\hline $\mathrm{R} 1$ vs $\mathrm{R} 2, \mathrm{R} 3, \mathrm{R} 4$ & 0.000 & 0.0187 \\
\hline R2 vs R3,R4 & 0.602 & 3.9786 \\
\hline R3 vs R4 & $10.256 * *$ & $4.9452 *$ \\
\hline Average $\mathrm{R} 1, \mathrm{R} 2, \mathrm{R} 3, \mathrm{R} 4$ & 21.298 & 30.731 \\
\hline Average $R 2, R 3, R 4$ & 21.305 & 30.672 \\
\hline Avergae R3,R4 & 21.716 & 31.901 \\
\hline
\end{tabular}

Note: $\quad *$ significant effect $(P<0.05)$;

$* *$ highly significant effect $(P<0,01)$

Table 2. Dry matter and Crude Fiber of amofer corn cob

\begin{tabular}{cll}
\hline Treatments & $D M(\%)$ & $C F(\%)$ \\
\hline$R O$ & 96.33 & 30.95 \\
$R 1$ & 94.80 & 31.79 \\
$R 2$ & 94.83 & 29.35 \\
$R 3$ & 93.65 & 30.17 \\
$R 4$ & 93.06 & 28.97 \\
F count & $6.65^{* *}$ & $54.31^{* *}$ \\
Ftab 0.05 & 2.87 & 2.87 \\
\hline
\end{tabular}

Note: $\quad * *=$ hhighly significant effect $(\mathrm{P}<0.01)$

The content of microorganism present in M21 Decomposer is able to produce enymes that degrade compounds in corn cobs. Actynomycetes as one of the microorganisms contained in M21 Decomposer are capable of producing lignocellulolytic enymes that can degrade liggnocellulose (Saini et al., 2015). Another microorganism in M21 Decomposer, Pseudomonas, is able to produce potease, amylase and lipase enzymes that can degrrade proteins, carbohydrates and other organic matter into $\mathrm{CO}_{2}$, ammonia gas and other simpler compounds (Hardhianto, 2010)

\section{The effect of treatments on the organic matter digestibility}

The result of OMD analysis showed that treatment RO was significantly different
$(P<0.05)$ from that of $R 1, R 2, R 3$, and R4. High DMD in amofer corn cobs was relevant to that of OMD. Similarly, Prastyawan et al. (2012) stated that organic matter and dry matter digestibility had the same pattern. The higher OMD of amofer corn cobs was because of the increased level of organic matter in the corn cobs. Fitria et al. (2019) reported that corn cobs treated with ammonia fermentation using M21 Decomposer could increase the level of organic matter in the corn cobs.

The OMD of treatment $R_{4}$ is significantly higher $(P<0,05)$ from that of $R_{3}$. The digestibility of organic matter in the $\mathrm{R}_{4}$ treatment increased by $8,252 \%$ compared to the untreated corn cobs $\left(R_{0}\right)$. It was because of the low crude fiber in amofer corn cob $\sin R_{4}$. It is evident from the 
proximate analysis (Table 2 ) that the crude fiber of treatment $R_{4}$ was the lowest of other treatments. Additionally, high crude fiber could decrease the digestibility of a feedstuff (Yulistiani et al., 2017). Crude fiber is a complex carbohydrate that is difficullt to digest so the lower crude fiber in a feed results in higher digestibiliy and vice versa. The decreased crude fiber in the amofer corn cobs due to microbial fermentation could increase the degradation potential of a compound in feedstuff (Riswara et al., 2018)

\section{Conclusions}

The treatments in this study significantly affected the digestibility of both dry matter and organic matter of corn cobs treated with ammonia fermentation consisted of $0.06 \%$ M21 Decomposer and $5 \%$ urea. This study reported $24.655 \%$ dry matter digestibility and $34.276 \%$ organic matter digestibility.

\section{Acknowledgement}

This research is undertaken with a research grant for junior lecturers from the Directorate of Research and Community Service.

\section{References}

Central Java BPS. 2018. Harvested Area, Production and Productivity of Maize and Soybean by Regency/Municipality in Central Java Province, 2015. https://jateng.bps.go.id/ statictable. (accessed on October 9).
Fitria, R., D.P. Candrasari., dan N. Hindratiningrum. 2019. Water Content and Ash Content of Corncob Ammoniation Fermentation Using Commercial Starters (M21 Decomposer). Bulletin of Applied Animal Research. 1(2): 11 - 14.

Hardhianto, M.D. 2010. Efektifitas Bakteri Pseudomonas sebagai Pengurai Bahan Organik (Protein, Karbohidrat, Lemak) pada Air Limbah Pembenihan Ikan Lele Dumbo (Clarias sp.) Sistem Resirkulasi Tertutup. Fisheries and Marine Depatrment Airlangga University. Surabaya.

Prastyawan, R.M., B.I.M Tampoebolon dan Surono. 2012. Peningkatan Kualitas Janggel Jagung melalui Teknologi Amoniasi Fermentasi (AMOFER) terhadap Kecernaan Bahan Kering dan Bahan Organik serta Protein Total secara In Vitro. Animal Agriculture Journal. 1(1): 611-621.

Riswara, A.D., L.K. Nuswantara dan J. Achmadi. 2018. Kecernaan Nutrien secara In Vitro pada Fodder Jagung Hidroponik dengan Media Perendaman dan Penggunaan Dosis Pupuk yang Berbeda. JITP. 6(2): $110-114$.

Saini, A., Neeraj K. Aggarwal., A. Sharma, dan A. Yadav. 2015. Review Article: Actinomycetes: A Source of Lignocellulolytic Enzymes. Hindawi Publishing Corporation Enzyme Research.(2015): 15 pages.

Tilley, J.M.A. and R.A. Terry. 1963. A two-stage technique for the in vitro digestion of forage crops Current Contents. J.British Grass.Soc. 18:104-111.

Yulistiani, D., W. Puastuti, E. Wina, dan Supriati. 2011. Pengaruh Berbagai Pengolahan terhadap Nilai Nutrisi Janggel Jagung: Komposisi Kimia dan Kecernaan In Vitro. JITV. 17(1): 59 - 66.

Yulistiani, D., W. Puastuti, B. Haryanto, A. Purnomoadi, M. Kurihara and A. Thalib. 2017. Complete Rumen Modifier Supplementation in Corn Cob Silage Basal Diet of Lamb Reduces Methan Emission. Indonesian Journal of Agriculture Science. 18(1): $33-42$. 